\title{
Metal Speciation in Surface Sediments of the Uberabinha River in Uberlândia, MG State, Brazil
}

\author{
Luciano A. da Silva, ${ }^{a}$ Luciana M. Coelho, ${ }^{b}$ Vania Rosolen ${ }^{c}$ and Nívia M. Melo Coelho ${ }^{* a}$ \\ ${ }^{a}$ Instituto de Química and 'Instituto de Geografia, Universidade Federal de Uberlândia, \\ Av. João Naves de Ávila, 2121, 38400-902 Uberlândia-MG, Brazil
}

${ }^{b}$ Departamento de Química, Universidade Federal de Goiás, Av. Doutor Lamartine Pinto de Avelar, 1120, Setor Universitário, 75704-020 Catalão-GO, Brazil

\begin{abstract}
O procedimento de extração em três etapas sequenciais recomendado pelo Programa de Normas Europeias de Medições e Ensaios (SM\&T), anteriormente nomeado por Gabinete Comunitário de Referência (BCR), foi aplicado para a especiação química de metais pesados ( $\mathrm{Cu}, \mathrm{Pb}, \mathrm{Cr}$ e $\mathrm{Zn}$ ) em sedimentos provenientes de diferentes regiões urbanizadas da Cidade de Uberlândia (MG, Brasil). Para obter o balanço de massa, uma quarta etapa, ou seja, a digestão do resíduo foi realizada através do processo de digestão assistida por micro-ondas em meio ácido. Maiores concentrações dos elementos metálicos foram encontradas em pontos de amostragem que recebem descarga de uma área urbana e uma zona industrial. Todos os metais, exceto Zn, estavam presentes em maiores concentrações nas frações residuais (fortemente associados com as estruturas cristalinas dos minerais), indicando que $\mathrm{Cu}, \mathrm{Pb}$ e $\mathrm{Cr}$ foram menos móveis e potencialmente menos biodisponíveis nesses sedimentos. Em sedimentos de zonas de descargas industriais e urbanas, a sequência de mobilidade dos metais estudados foi $\mathrm{Pb}>\mathrm{Zn}>\mathrm{Cu}>\mathrm{Cr}$. Maiores concentrações de $\mathrm{Pb}$ foram encontradas nas frações residuais no ponto de amostragem localizado no afluente que drena a zona industrial (102 mg kg-1), indicando que este elemento metálico foi fortemente ligado aos sedimentos. Portanto, sob os pontos de vista toxicológico e ambiental, o $\mathrm{Pb}$ não causa impacto ao meio ambiente e consequentemente à saúde humana. A soma das quatro frações (solúvel em ácido, redutível, oxidável e residual) apresentou boa concordância com o teor total, o que comprova a exatidão do procedimento de extração por micro-ondas em conjunto com o método analítico FAAS.
\end{abstract}

A three-step sequential extraction procedure recommended by the European Standards, Measurements and Testing (SM\&T) Program, formerly the Community Bureau of Reference (BCR), was applied to the chemical speciation of heavy metals $(\mathrm{Cu}, \mathrm{Pb}, \mathrm{Cr}$ and $\mathrm{Zn})$ in sediments from different populated zones of Uberlândia City (MG State, Brazil). To obtain a mass balance, a fourth step, i.e., digestion and analysis of the residue, was performed using a microwave-assisted acid digestion procedure. The highest metallic elements concentrations were observed at one of the sampling points which receive discharge from an urban area and an industrial zone. All metals, except $\mathrm{Zn}$, were present at higher concentrations in the residual fractions (strongly associated with the crystalline structures of the minerals) indicating that $\mathrm{Cu}, \mathrm{Pb}$ and $\mathrm{Cr}$ were less mobile and potentially less bioavailable in these sediments. In sediments from industrial and urban discharge zones the mobility sequence of the heavy metals studied was $\mathrm{Pb}>\mathrm{Zn}>\mathrm{Cu}>\mathrm{Cr}$. The highest $\mathrm{Pb}$ concentrations were found in the residual fractions at the sampling point located in the tributary stream that drains the industrial district $\left(102 \mathrm{mg} \mathrm{kg}^{-1}\right)$, indicating that this metallic element was strongly bound to the sediments. Therefore, under the contamination and toxicological point of view, $\mathrm{Pb}$ has no impact to the environment and consequently to the human health. The sum of the four fractions (acid-soluble + reducible + oxidizable + residual) was in good agreement with the total content, which verifies the accuracy of the microwave extraction procedure in conjunction with the FAAS analytical method.

Keywords: sediments, metal speciation, BCR sequential extraction

*e-mail: nmmcoelho@ufu.br 


\section{Introduction}

The contamination of sediments, soils and biota by heavy metals is of major concern especially in many industrialized countries due to the persistent and nonbiodegradable properties of these contaminants.

Sediments are the main repository and source of heavy metals in the environment and play an important role in the transport and storage of potentially hazardous metals. ${ }^{1,2}$

The total metal content in polluted environmental samples is a poor indicator of the bioavailability, mobility or toxicity of the metals. These proprieties are basically dependent on the different chemical forms of binding between the metals and solid phases of the sample. Metal ions in sediments are partitioned between the different phases, i.e., organic matter; oxyhydroxides of iron, aluminum and manganese; silicate minerals; carbonates and sulfites. ${ }^{3}$ Although the separation of various chemical forms of heavy metals is very difficult, the use of sequential extraction methods does provide important information. ${ }^{4}$

Sequential extraction procedures have been widely used for determining specific chemical forms of heavy metals in a range of environmental media, including sediments and waste materials. ${ }^{5-8}$ The number of steps in these extractions varies from three to six and the extraction procedures adopted can show different results. ${ }^{9-12}$ However, since the extraction sequences and operating conditions involved in these procedures differ, it is difficult to compare the data obtained with these methods.

In response to this situation, the European Community Bureau of Reference established a BCR three-step sequential extraction program aimed at standardizing the sequential extraction procedure for trace metal speciation in sediments. ${ }^{9}$ The principle of this procedure is based on the selective extraction of heavy metals in different physicochemical fractions of a material using specific solvents. The extractants commonly used in BCR sequential extraction schemes fall, generally, within the following groups: acetic acid (step 1), reducing agents (step 2) oxidizing agents (step 3 ). ${ }^{13}$ According to this procedure, the first extractable fraction is the exchangeable, the second the reducible and the third the oxidizable fraction. ${ }^{14-16}$

Several studies in Brazil have highlighted serious problems of sediment contamination and the high potential bioavailability of metals in reservoirs and river segments downstream from urban centers. ${ }^{17-20}$ These results provide useful information regarding the origin, mode of occurrence, bioavailability, potential mobility and transport of elements in the natural environmental.

The aim of this study was to evaluate the concentrations of $\mathrm{Cu}, \mathrm{Pb}, \mathrm{Cr}$ and $\mathrm{Zn}$ in recent sediments deposited in some stretches of the Uberabinha River (Uberlândia, MG, Brazil) in order to understand the effects of anthropogenic activities and the risks to the environment and human health. The sediments collected from five points along the Uberabinha River were analyzed using a BCR sequential extraction procedure. The proposed method was validated against the microwave-assisted acid digestion procedure using flame atomic absorption spectrometry (FAAS) for the quantitative determination of total and extracted metals.

\section{Experimental}

\section{Reagents}

Deionized water (resistivity $18.2 \mathrm{M} \Omega \mathrm{cm}$ ) obtained from a Gehaka Master System (São Paulo, Brazil) was used throughout. Ultra-pure $\mathrm{HNO}_{3}$ (Fluka), $\mathrm{H}_{2} \mathrm{O}_{2}$ (Vetec), $\mathrm{HCl}$ (Vetec), ammonium acetate (Vetec) and analytical grade acetic acid (Synth), hydroxylamine hydrochloride (Vetec) were used as the sequential extraction reagents in conjunction with microwave-assisted acid digestion.

\section{Apparatus}

A Varian SpetrAA-220 flame atomic absorption spectrometer (FAAS) was used for the determination of heavy metals in the sequential extracts. The instrument parameters for metal analysis were as recommended by the manufacturer. Sediment extractions were conducted using a mechanical shaker (Model Tecnal TE141, Brazil) at $30 \pm 10 \mathrm{rpm}$ for $16 \mathrm{~h}$. A centrifuge (Model Gemmy PLC-03, Taiwan) was used to obtain the supernatant extracts at $3000 \mathrm{rpm}$ for $20 \mathrm{~min}$. A microwave unit (Model Provecto DGT-100, Brazil) was used for the total digestion of sediment samples. All 'labware' was made of polypropylene, high density polyethylene or polytetrafluoroethylene which had been prepared for use by pre-washing in laboratory-grade detergent, rinsing with deionized water, and soaking in $2 \% \mathrm{HNO}_{3}$ (overnight), followed by thorough rinsing with deionized water.

\section{Study area}

Sediment samples were collected from five sites in Uberlândia City: (P1) one of the water reservoirs for public supply (Sucupira Reservoir); (P2) a densely urbanized area near a domestic wastewater discharge point; (P3) a point located on a tributary stream that drains the industrial district around $25 \mathrm{~m}$ before the confluence with the Uberabinha River; (P4) the confluence of the tributary known as the "Córrego Liso" with the Uberabinha River; 
and (P5) a point downstream on the Uberabinha River (see Figure S1). Uberlândia is an important city in Minas Gerais State (Brazil) localized at $19^{\circ} 0^{\prime} \mathrm{S}$ and $48^{\circ} 20^{\prime} \mathrm{W}$. The Uberabinha River crosses the metropolitan area of Uberlandia, which has a population of nearly 700 thousand people, and receives considerable loads of industrial and domestic wastes. The choice of sampling sediments in these regions is due to the fact that the predominant activities are agricultural, with the intensive use of fertilizers and pesticides, mining, the urban and industrial areas of Uberlândia, and finally the presence of dams and reservoirs to generation energy.

\section{Sample collection and preparation}

Triplicate sediment samples were collected from the near surface layer $(10-15 \mathrm{~cm})$ along the river, close to the flood plains. The sediments were collected using a grab sampler and sub-sampled with a plastic spoon. Samples were stored in polyethylene bags and kept in a freezer at $-10{ }^{\circ} \mathrm{C}$ prior to processing and analysis. In the laboratory, samples were defrosted and air-dried at $30 \pm 2{ }^{\circ} \mathrm{C}$ and then ground with a pestle and mortar and sieved $(<63 \mu \mathrm{m})$. The $<63 \mu \mathrm{m}$ fraction was used for analysis in this study due to the strong association of metals with fine-grained sediments. ${ }^{21}$ The moisture content of the dried sample was calculated by heating a portion of sediment in an oven at $105 \pm 2{ }^{\circ} \mathrm{C}$ to constant weight. Sediment data in this study are reported on a dry weight basis.

\section{Sequential extraction method}

\section{Step 1 (acid-soluble fraction - bound to carbonates)}

For each sample, three $1.0 \mathrm{~g}$ dry sediment replicates were placed into $60 \mathrm{~mL}$ polypropylene centrifuge tubes. Forty milliliters of $0.11 \mathrm{~mol} \mathrm{~L}^{-1}$ acetic acid was added to the tube which was then shaken for $16 \mathrm{~h}$ at room temperature of $\left(25 \pm 5{ }^{\circ} \mathrm{C}\right)$ at a speed of $30 \pm 10 \mathrm{rpm}$. The extract was separated from the solid phase by centrifugation at $3000 \mathrm{rpm}$ for $20 \mathrm{~min}$. The supernatant liquid was decanted into a $60 \mathrm{~mL}$ polypropylene centrifuge tube and stored in a refrigerator at $4{ }^{\circ} \mathrm{C}$ prior to analysis. The residue was washed with $10 \mathrm{~mL}$ of deionized water and shaken again for $15 \mathrm{~min}$ and then centrifuged for $20 \mathrm{~min}$ at $3000 \mathrm{rpm}$. The supernatant was decanted and removed carefully to avoid loss of the solid residue.

\section{Step 2 (reducible fraction - bound to Fe and Mn oxides)}

Forty milliliters of $0.1 \mathrm{~mol} \mathrm{\textrm {L } ^ { - 1 }}$ hydroxylamine hydrochloride (adjusted to $\mathrm{pH}$ of around 2.0 by adding of $2 \mathrm{~mol} \mathrm{~L}^{-1} \mathrm{HNO}_{3}$ ) was added to the residue from step 1 in the centrifuge tube. Again, the tube was shaken for $16 \mathrm{~h}$ at $25 \pm 5^{\circ} \mathrm{C}$ at a speed of $30 \pm 10 \mathrm{rpm}$. The extract was separated from the solid phase by centrifugation and decantation as described for step 1 and stored at $4{ }^{\circ} \mathrm{C}$. The solid residue was washed as in step 1 before proceeding to step 3 .

\section{Step 3 (oxidizable fraction - bound to organic matter and sulfides)}

Ten milliliters of $8.8 \mathrm{~mol} \mathrm{~L}^{-1} \mathrm{H}_{2} \mathrm{O}_{2}$ ( $\mathrm{pH}$ of 2-3) was added carefully, in small aliquots, to the residue from step 3 in the centrifuge tube. The tube was covered loosely and digested at room temperature for $1 \mathrm{~h}$ with occasional shaking. The sample in the tube was then continuously digested for $1 \mathrm{~h}$ at $85 \pm 2{ }^{\circ} \mathrm{C}$ in a water bath with occasional shaking for the first $30 \mathrm{~min}$, and the volume was then reduced to around $2-3 \mathrm{~mL}$ by further heating of the uncovered tube. After cooling, $50 \mathrm{~mL}$ of $1.0 \mathrm{~mol} \mathrm{~L} \mathrm{~L}^{-1}$ ammonium acetate (adjusted to $\mathrm{pH} 2$ by adding of concentrated $\mathrm{HNO}_{3}$ ) was added to the residue and the tube was shaken for $16 \mathrm{~h}$ at room temperature. The extract was separated from the solid phase as described above and stored at $4{ }^{\circ} \mathrm{C}$.

Step 4 (residual fraction - strongly associated with the crystalline structures of the minerals)

The residue from Step 3 was digested in a mixture (1:2) of concentrated $\mathrm{HCl}$ and $\mathrm{HNO}_{3}$. Samples were heated in the microwave unit. The program was 400 watts $(5 \mathrm{~min})$, 660 watts (10 min), 400 watts ( $5 \mathrm{~min})$ and 0 watts (10 min). After cooling, the digests were centrifuged at $3000 \mathrm{rpm}$ for $10 \mathrm{~min}$ to clarify the supernatant which was then analyzed by FAAS using a Varian SpectrAA-220. Also, the samples were directly digested using the microwaveassisted acid digestion procedure in order to quantify the total metal contents.

\section{Microwave-assisted acid digestion procedure}

Three replicates of $1.0 \mathrm{~g}$ of samples were analyzed by digestion with a mixture of acid $(3 \mathrm{~mL}$ concentrated $\mathrm{HCl}$ and $7 \mathrm{~mL}$ concentrated $\mathrm{HNO}_{3}$ ). Samples were heated in the microwave unit. The program was as described above. After cooling, the digests were centrifuged at $3000 \mathrm{rpm}$ for 10 min to clarify the supernatant which was then analyzed by FAAS.

\section{Results and Discussion}

\section{Physico-chemical studies}

The aim of this study was to evaluate the concentrations of $\mathrm{Cu}, \mathrm{Pb}, \mathrm{Cr}$ and $\mathrm{Zn}$ in recent sediments deposited in some 
stretches of the Uberabinha River. So, the physico-chemical parameters (i.e., organic matter, organic carbon, aluminum, phosphate, silica, etc) of sediment samples were performed by previous published studies. ${ }^{23}$ These studies showed that the sediment samples are compatible with the source areas, consisting of the lateritic soils (Oxisols and Ultisols). The experimental results indicated values from 69.4-77.8\%; 4.9-0.9\%; 3.5-10.4\% for $\mathrm{SiO}_{2}, \mathrm{Al}_{2} \mathrm{O}_{3}$ and $\mathrm{Fe}_{2} \mathrm{O}_{3}$, respectively. The total carbon in these samples ranged from 1.4 to $1.5 \%$. The $\mathrm{pH}$ values for each batch were determined, using a ratio of 1:2.5 (sediment and ultrapure water). The $\mathrm{pH}$ values were observed to be in the range of 6.2-7.5.

\section{Validation of the method}

In order to verify the accuracy of the sequential extraction method, the results for the sum of the four extraction steps of the BCR method, including the residual phase, were compared with those obtained for the total extraction using the microwave-assisted acid digestion procedure. The sum of the extractable contents and percentage recoveries in relation to the content found in the microwave digests are presented in Table 1. Recoveries were good, averaging $92-104 \%$, indicating that the sum of the values for the four fractions is in agreement with the total metal contents in all cases.

\section{Total metal content}

The total contents of $\mathrm{Cu}, \mathrm{Pb}, \mathrm{Cr}$ and $\mathrm{Zn}$ in the sediment samples are summarized in Table 1. Mean contents of $\mathrm{Cu}$, $\mathrm{Cr}$ and $\mathrm{Zn}$ in the samples were within the normal range and likely to be controlled by the National Council on the Environment (CONAMA 344/04). ${ }^{24}$ This legislation establishes limit concentration values for metals in dredged materials that may cause adverse effects to the aquatic biota and to humans. The TEL (threshold effect level) represents the concentration below which adverse effects to organisms are rarely expected. The higher limit - PEL (probable effect level) - represents the concentration above which the potential for adverse effects on organisms and the environment are often cited. In the range between TEL and PEL values are occasionally found where such effects are expected. Table 2 shows the guideline values established by CONAMA 344/04 for the metals $\mathrm{Cr}, \mathrm{Cu}, \mathrm{Pb}$ and $\mathrm{Zn}$. The $\mathrm{Pb}$ content was higher than the established limit and may be originated from an anthropogenic source.

There were apparent differences between the five sampling sites in terms of the total metal contents, where the concentrations of all metals, except for $\mathrm{Pb}$, in the sediments from P2 and P5 were greater than those from P1, P3 and P4.
Anthropogenic discharges may explain the elevated levels of heavy metals in sediments from P2 and P5. Moreover, the water flows in the regions close to the city which result in the accumulation of pollutants, especially heavy metals, in sediments may account for the higher levels present in sediments from P5. Metal concentrations decreased in the order $\mathrm{Pb}>\mathrm{Zn}>\mathrm{Cr}>\mathrm{Cu}$ in the densely urbanized area close to the point of domestic wastewater release. Among the heavy metals determined in the sediments, $\mathrm{Pb}$ was present at the highest concentration for all sampling sites.

Table 1. Comparative results for the BCR sequential extraction and total acid microwave (MW) digestion of the sediment samples

\begin{tabular}{|c|c|c|c|c|}
\hline Metal & Sampling points & $\mathrm{BCR} /\left(\mathrm{mg} \mathrm{kg}^{-1}\right)$ & $\mathrm{MW} /\left(\mathrm{mg} \mathrm{kg}^{-1}\right)$ & $\%$ \\
\hline \multirow[t]{5}{*}{$\mathrm{Cu}$} & $\mathrm{P} 1$ & $43.60 \pm 1.47$ & $44.99 \pm 0.92$ & 97 \\
\hline & $\mathrm{P} 2$ & $42.06 \pm 2.08$ & $43.69 \pm 3.35$ & 97 \\
\hline & P3 & $25.74 \pm 1.00$ & $26.51 \pm 2.32$ & 97 \\
\hline & P4 & $27.65 \pm 1.23$ & $28.39 \pm 3.84$ & 96 \\
\hline & P5 & $64.85 \pm 0.85$ & $65.45 \pm 4.43$ & 99 \\
\hline \multirow[t]{5}{*}{$\mathrm{Pb}$} & $\mathrm{P} 1$ & $166.01 \pm 5.07$ & $169.86 \pm 2.52$ & 98 \\
\hline & P2 & $177.33 \pm 3.22$ & $182.80 \pm 0.55$ & 97 \\
\hline & P3 & $175.42 \pm 2.77$ & $175.65 \pm 4.24$ & 100 \\
\hline & P4 & $177.49 \pm 3.21$ & $181.47 \pm 0.27$ & 98 \\
\hline & P5 & $132.87 \pm 3.64$ & $133.27 \pm 3.11$ & 99 \\
\hline \multirow[t]{5}{*}{$\mathrm{Cr}$} & $\mathrm{P} 1$ & $29.33 \pm 2.85$ & $29.42 \pm 6.09$ & 99 \\
\hline & P2 & $43.64 \pm 1.46$ & $45.50 \pm 2.50$ & 96 \\
\hline & P3 & $34.43 \pm 1.46$ & $35.65 \pm 1.99$ & 96 \\
\hline & P4 & $13.55 \pm 2.09$ & $14.14 \pm 4.25$ & 96 \\
\hline & P5 & $64.33 \pm 3.06$ & $65.63 \pm 2.11$ & 98 \\
\hline \multirow[t]{5}{*}{$\mathrm{Zn}$} & $\mathrm{P} 1$ & $24.48 \pm 0.37$ & $24.58 \pm 3.14$ & 99 \\
\hline & $\mathrm{P} 2$ & $101.11 \pm 4.05$ & $96.69 \pm 5.24$ & 104 \\
\hline & P3 & $36.97 \pm 2.12$ & $37.78 \pm 0.80$ & 98 \\
\hline & P4 & $39.40 \pm 0.78$ & $40.15 \pm 1.00$ & 98 \\
\hline & P5 & $59.97 \pm 0.67$ & $64.99 \pm 3.39$ & 92 \\
\hline
\end{tabular}

Table 2. Reference values established by CONAMA for dredged materials ${ }^{\mathrm{a}}$

\begin{tabular}{lcc}
\hline Metal & \multicolumn{2}{c}{ Conc. / $\left(\mathrm{mg} \mathrm{kg}^{-1}\right)$} \\
\cline { 2 - 3 } & TEL* & PEL** \\
\hline $\mathrm{Pb}$ & 35 & 91.3 \\
$\mathrm{Cu}$ & 35.7 & 197 \\
$\mathrm{Cr}$ & 37.3 & 90 \\
$\mathrm{Zn}$ & 123 & 315 \\
\hline
\end{tabular}

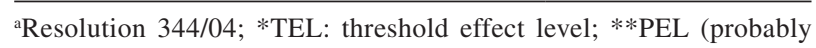
effect level).

\section{Metal speciation}

The sequential extraction procedure allowed determination of the distribution of the trace metals between the different geochemical fractions, reflecting the relative proportions of each metal transported by different chemical mechanisms. The acid soluble fraction shows the amount of 
each element that would be released into the environment if conditions became more acidic. It is the fraction with the most labile bonding to the sediment and, therefore, presents the greatest environmental risk. The reducible fraction theoretically represents the content of each metal bound to iron and manganese oxides that would be released if the sediment were subjected to more reducing conditions. The oxidizable fraction reflects the amount of metal bound to the organic matter and sulfides, which would be released if conditions became oxidizing. The residual fraction contains the metals with the strongest association with the crystalline structures of the minerals, and which are therefore the most difficult to separate from the sediments.

The extractable contents of $\mathrm{Cu}, \mathrm{Pb}, \mathrm{Cr}$ and $\mathrm{Zn}$, and the extracted amounts of these metals with respect to the sum of the four fractions in the sediments from each extraction step are shown in Figures 1, 2, 3 and 4, respectively. All metals except for $\mathrm{Zn}$ were present at higher amounts in the residual fractions (strongly associated to the crystalline

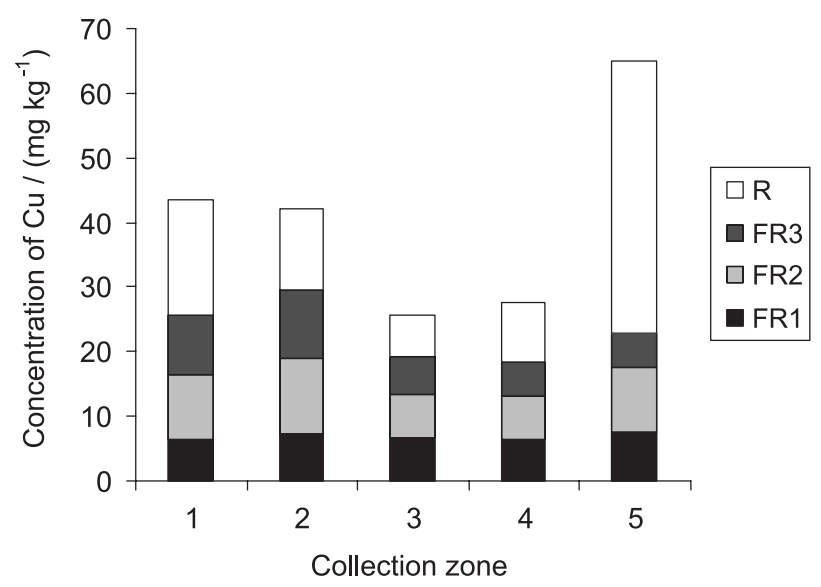

Figure 1. Distribution of $\mathrm{Cu}$ in fractions obtained through sequential extraction. FR1: Fraction 1 (acid extractable), FR2: Fraction 2 (reducible), FR3: Fraction 3 (oxidizable), R: Residual.

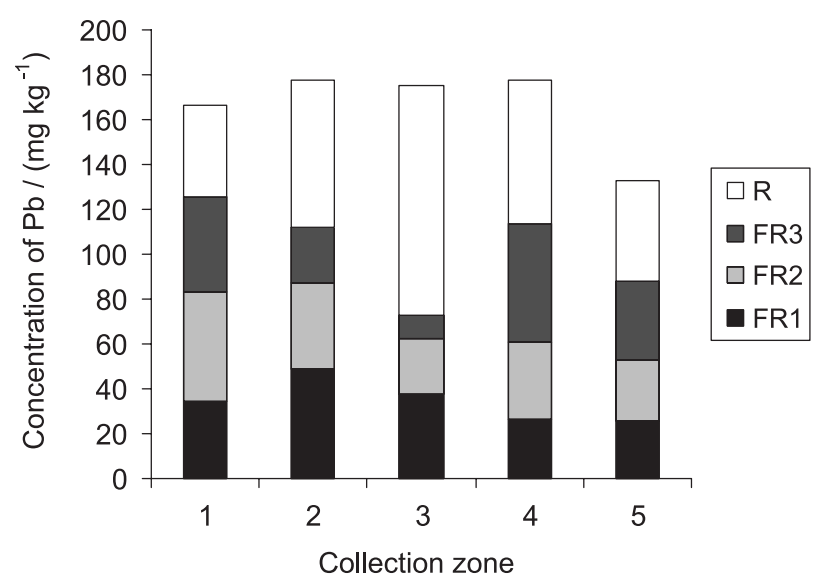

Figure 2. Distribution of $\mathrm{Pb}$ in fractions obtained through sequential extraction. FR1: Fraction 1 (acid extractable), FR2: Fraction 2 (reducible), FR3: Fraction 3 (oxidizable), R: Residual. structures of the minerals) indicating that $\mathrm{Cu}, \mathrm{Pb}$ and $\mathrm{Cr}$ were less mobile and potentially less bioavailable in these sediments. These results are consistent with the findings for river and lagoon sediments of Rio de Janeiro (Brazil) where $\mathrm{Zn}$ was the metal of greatest concern with respect to the system pollution. ${ }^{18}$

The nonresidual fractions (acid-soluble + reducible + oxidizable) of $\mathrm{Cu}$ and $\mathrm{Zn}$ in the sediments were greatest in P2 (30 $\mathrm{mg} \mathrm{kg}^{-1}$ for $\mathrm{Cu}$ and $92 \mathrm{mg} \mathrm{kg}^{-1}$ for $\mathrm{Zn}$ ), i.e., an area receiving domestic wastes. These results indicate that heavy metals in sediments close to points of domestic wastewater discharge are potentially more available for exchange and/ or release into the environment relative to those from other sites studied. The mobility of the heavy metals studied decreased in the order $\mathrm{Pb}>\mathrm{Zn}>\mathrm{Cr}>\mathrm{Cu}$.

The dominant proportion of $\mathrm{Pb}$ was found in the oxidizable fraction $\left(50 \mathrm{mg} \mathrm{kg}^{-1}\right)$ in the sediment from the confluence point of the tributary "Córrego Liso" with the Uberabinha River, probably due to the higher content of

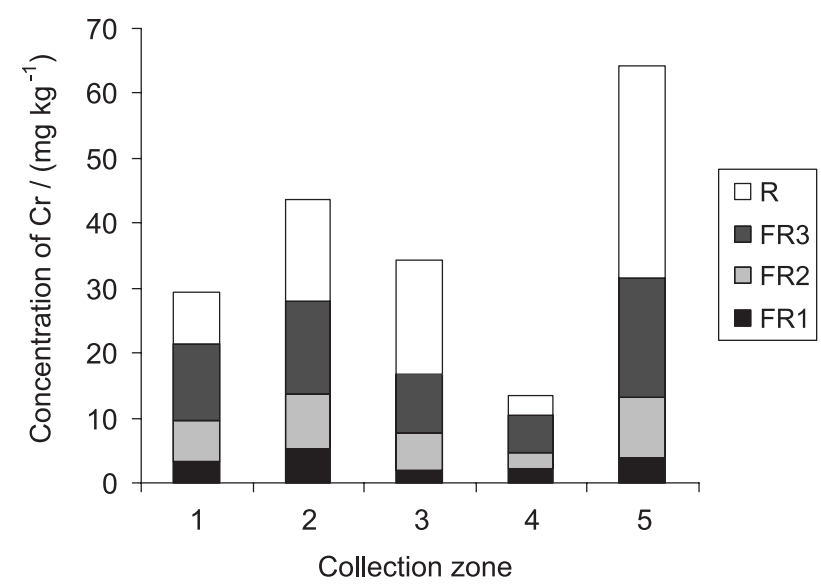

Figure 3. Distribution of $\mathrm{Cr}$ in fractions obtained through sequential extraction. FR1: Fraction 1 (acid extractable), FR2: Fraction 2 (reducible), FR3: Fraction 3 (oxidizable), R: Residual.

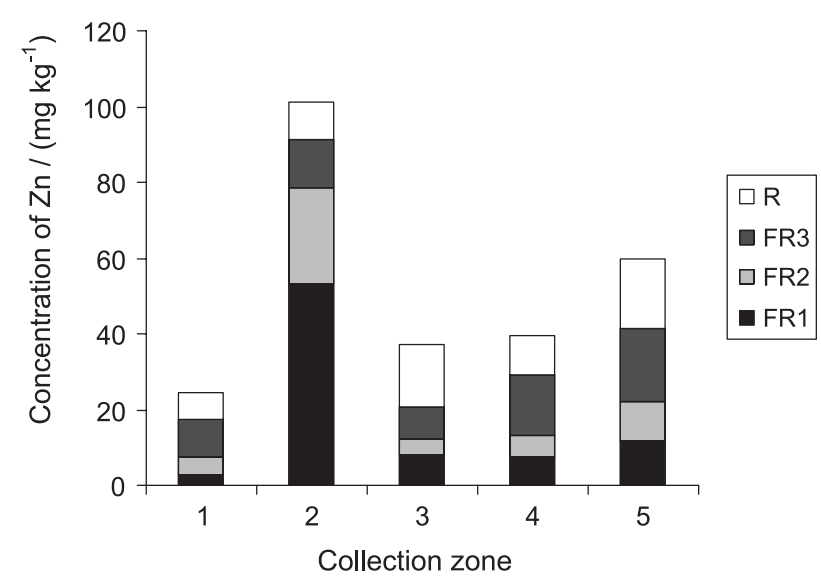

Figure 4. Distribution of $\mathrm{Zn}$ in fractions obtained through sequential extraction. FR1: Fraction 1 (acid extractable), FR2: Fraction 2 (reducible), FR3: Fraction 3 (oxidizable), R: Residual. 
organic matter and sulfides which are substances that can be easily oxidized. In contrast, at the point located on the tributary stream that drains the industrial district (P3), the highest concentration (102 $\mathrm{mg} \mathrm{kg}^{-1}$ ) was found in the residual fraction, the most chemically recalcitrant and least bioavailable in the sediments.

Chromium was mainly bound to organic matter and sulfides, particularly in sediments from the point downstream on the Uberabinha River, where the highest percentage was found in the oxidizable fraction. The high stability constant of organic $\mathrm{Cr}$ compounds results in stable complex formation between $\mathrm{Cr}$ and organic matter. ${ }^{22}$ These results are consistent with the findings from sediments of the Tietê-Pinheiros river system in São Paulo state where the metals are associated to a large degree with reactive forms such as sulfides and carbonates, or adsorbed to amorphous oxyhydroxides of $\mathrm{Fe}$ and $\mathrm{Mn} .{ }^{17}$

The highest amount of $\mathrm{Cu}$ was found in the residual fractions of the sample collected from the downstream point on the Uberabinha River ( $42 \mathrm{mg} \mathrm{kg}^{-1}$ ) indicating that this metal was strongly associated with the crystalline structures of the sediments.

The distribution of the metals indicated the recent pollution by $\mathrm{Pb}$ for samples from the Sucupira reservoir. In the samples, the heavy metals are mainly associated with the residual fraction, suggesting that their concentrations are controlled significantly by transport processes with fine particles acting as carriers from diffuse pollution sources.

\section{Conclusions}

The BCR sequential extraction procedure was applied to sediments from five locations in the city of Uberlândia, MG State, Brazil, in order to evaluate the potential mobility and transfer of heavy metals from sediments to the surrounding environment. Moreover, in order to identify the storage of heavy metals in sediments, the total metal contents were determined. This represents the first study of its kind in Uberlândia. The study indicates that sediments in an area receiving domestic wastewater are more contaminated with heavy metals than those in an industrial area. However, since sediments can act as a reservoir for heavy metals, their potential risk to the environment must be considered. The results obtained in this study clearly show that urbanization and agriculture have a major influence on transport and accumulation of potentially toxic substances in sediments of Uberabinha River. Therefore, due to diffuse sources is very difficult to identify the source areas, to control and mitigate the effects of pollution.

Based on the analytical data obtained from the BCR sequential extraction procedure, it can be concluded that all metals determined are mobile and bioavailable. With a change in the prevailing environmental conditions (e.g., $\mathrm{pH}$, redox potential, etc) heavy metal transfer from the sediments to the water column can be expected to occur more readily in sediments from domestic wastewater than in industrial areas. Among the elements analyzed, Zn had the highest mobility while $\mathrm{Cr}$ was the least labile.

The applications of sequential extraction methods to environmental samples provide relevant information about possible toxicity when they are discharged into the environment. Understanding of the mobility of potential toxic elements and how they might transfer under human induced conditions are essential for developing the future remediation plans and pollution control in surface sediments, in particular from the considered Uberabinha River.

\section{Supplementary Information}

Supplementary data are available free of charge at http://jbcs.sbq.org.br as PDF file.

\section{Acknowledgments}

The authors are grateful for financial support from the Brazilian government agencies Conselho Nacional de Desenvolvimento Científico e Tecnológico (CNPq) and Coordenação de Aperfeiçoamento de Pessoal de Nível Superior (CAPES), from the MG state government agency Fundação de Amparo à Pesquisa do Estado de Minas Gerais (FAPEMIG) and GO state government agency Fundação de Amparo à Pesquisa do Estado de Goiás (FAPEG).

\section{References}

1. Adriano, D. C.; Wenzel, W. W.; Vangronsveld, J.; Bolan, N. S.; Geoderma 2004, 122, 121.

2. Ahlf, W.; Förstner, U.; J. Soils Sediments 2001, 2, 30.

3. Alloway, B. J. In Heavy Metals in Soils; Alloway, B. J., ed.; John Wiley: New York, 1990, pp. 29-39.

4. Quevauviller, P.; Trends Anal. Chem. 1999, 18, 302.

5. Long, Y. Y.; Hu, L. F.; Fang, C. R.; Wu, Y. Y.; Shen, D. S.; Microchem. J. 2009, 91, 1.

6. Mossop, K.; Davidson, C. M.; Anal. Chim. Acta 2003, 478, 111.

7. Cappuyns, V.; Swennen, R.; Niclaes, M.; J. Geochem. Explor. 2007, 93, 78 .

8. Cuong, D. T.; Obbard, J. P.; Appl. Geochem. 2006, 21, 1335.

9. Ure, A. M.; Quevauviller, P.; Muntau, H.; Griepink, B.; Int. J. Environ. Anal. Chem. 1993, 51, 135.

10. Kiratli, N.; Ergin, M.; Appl. Geochem. 1996, 11, 775.

11. Tessier, A.; Campbell, P. G. C.; Bisson, M.; Anal. Chem. 1979, 51,844 . 
12. Kersten, M.; Forstner, U.; Water Sci. Technol. 1986, 18, 121.

13. Gleyzes, C.; Tellier, S.; Astruc, M.; Trends Anal. Chem. 2002, 21,451 .

14. Davidson, C. M.; Duncan, A. L.; Littlejohn, D.; Ure, A. M; Garden, L. M.; Anal. Chim. Acta 1998, 363, 45.

15. Arain, M. B.; Kazi, T. G.; Jamali, M. K.; Afridi, H. I.; Jalbani, N.; Sarfraz, R. A.; Baig, J. A.; Kandhro, G. A.; Memon, M. A.; J. Hazard. Mater. 2008, 160, 235.

16. Ciceri, E.; Giussani, B.; Pozzi, A.; Dossi, C.; Recchia, S.; Talanta 2008, 76, 621.

17. Silva, I. S.; Abate, G.; Lichtig, J.; Masini, J. C.; Appl. Geochem. 2002, 17, 105.

18. Fernandes, H. M.; Environ. Pollut. 1997, 97, 317.

19. Perin, G.; Fabris, R.; Manente, S.; Rebello Wagener, A.; Hamacher, C.; Scotto, S.; Water Res. 1997, 31, 3017.
20. Teixeira, E. C.; Ortiz, L. S.; Alves, M. F. C. C.; Sanchez, J. C. D.; Environ. Geol. 2001, 41, 145.

21. Förstner, U.; Heise, S.; Schwartz, R.; Westrich, B.; Ahlf, W.; J. Soils Sediments 2004, 4, 247.

22. Morilo, J.; Usero, J.; Gracia, I.; Chemosphere 2004, 55, 431.

23. Rosolen, V; Herpin, U.; Coelho, N. M. M.; Coelho, L. M.; Brito, J. L.; Silva, L. A.; Lima, S. C.; Rev. Bras. Geociencias 2009, 39, 151.

24. CONAMA. Conselho Nacional do Meio Ambiente; Resolução 344/04; http://www.mma.gov.br accessed in September, 2011.

Submitted: April 15, 2011

Published online: September 6, 2011 


\section{Metal Speciation in Surface Sediments of the Uberabinha River in Uberlândia, MG State, Brazil}

\section{Luciano A. da Silva, ${ }^{a}$ Luciana M. Coelho, ${ }^{b}$ Vania Rosolen ${ }^{c}$ and Nívia M. Melo Coelho*,a}

${ }^{a}$ Instituto de Química and 'Instituto de Geografia, Universidade Federal de Uberlândia, Av. João Naves de Ávila, 2121, 38400-902 Uberlândia-MG, Brazil

${ }^{b}$ Departamento de Química, Universidade Federal de Goiás, Av. Doutor Lamartine Pinto de Avelar, 1120, Setor Universitário, 75704-020 Catalão-GO, Brazil

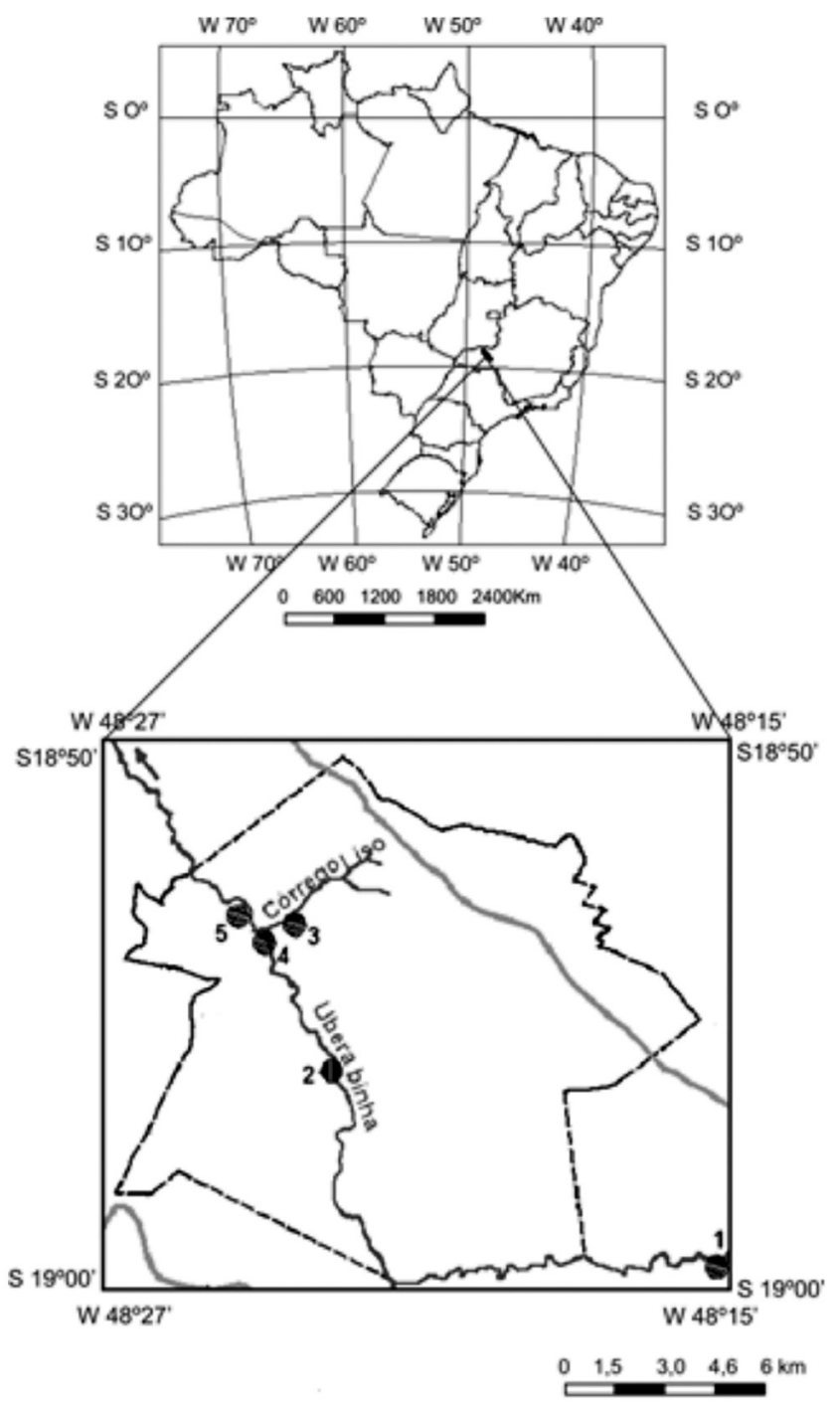

Figure S1. The figure shows location of sampling sites in Uberabinha River: Sucupira reservoir (1), close to domestic wastewater discharge point (2), industrial area (3), confluence point (4), Uberabinha River downstream (5). - Sample collection point, — stream, — limit of Uberabinha River watershed, .-.-. urban perimeter of Uberlândia. Source: LACAR/IG/UFU/2008.

*e-mail: nmmcoelho@ufu.br 